\section{Electric Power Supply in India}

$\mathrm{A}^{\mathrm{T}}$

T the annual meeting of the National Academy of Sciences, India, held on March 5, a symposium was arranged on the subject of India's power supply. In opening the discussion, Prof. M. N. Saha said that no subject could at the present moment be of greater importance than that of a cheap and abundant power supply. The whole industrial efficiency of a nation depends on it. He pointed out that there are countries in the world that have developed all their power resources-Norway, United States, England and Germany; but India, China and Abyssinia are still dependent on a medieval economy. In Norway, the total output per head per annum is nearly 1,800 units. In England and Germany the power is mainly derived from coal, but the output per head is probably nearly the same. In India the output cannot exceed 90 units, of which about 60 is from human labour, 10 from animal power and 20 from steam and electrical power combined.

If the problems of poverty and unemployment in India are to be solved, the power resources of the country must be organized so as to bring them to the level of Europe, America and Japan. Dr. Tandon said that the sponsors of the Ganges canal project would have done better service to the country if, instead of trying to capture the public imagination by the ideal of rural electrification, they had concentrated the load near the generating stations for the development of the heavy chemical industries.

Pandit J. Nehru, in summing up the discussion, said that everyone saw the necessity of establishing a power research and survey institute. But democratic Governments are greatly burdened by their ordinary routine work, and complaints from innumerable persons who now have access to them. The first things they do are naturally those demanded by hundreds of thousands of people, and so they have no time to listen to the counsels of a few dozen, however great their reputation may be. The expert man of science is not always a helpful person. $\mathrm{He}$ does not realize that things which have to be put before the Government must be definite and that the proposals must fit in with the realities of the situation. He asked the Academy to draw up definite proposals for benefiting the nation, and not vague aspirations as to what should or might be done.

At a subsequent meeting on March 29, Prof. Saha moved a series of resolutions which were unanimously carried. The Government is requested to appoint a committee of legal and scientific experts, and representatives of industry, to study the present Electricity Act and to recommend the necessary legislation required to nationalize the generation and distribution of electricity with the view of making the supply of electrical power in the country cheap and abundant. The second resolution requests the Government to select a body of graduates in physics and electrical and chemical engineering, and to send them to study the methods adopted in countries such as England, the U.S.S.R. and Switzerland. The third resolution is a request that a permanent body called the "Power Survey and Research Institute" be appointed. Finally, the National Academy noted with regret that the Government of the United Provinces, when appointing an Electricity Committee, did not consider it necessary to ask the Academy to nominate a specialist to serve on the Committee.

\section{Science News a Century Ago}

\section{Invention of Daguerrotype}

ON January 7, 1839, Arago described to the Paris Academy of Sciences the invention of Louis Jacques Mande Daguerre (1789-1851) for the photographic process of taking pictures on metal plates. Writing from Paris, a correspondent of the Athenceum said, "So universal an interest was excited here by the paper read by M. Arago, that I called on M. Daguerre to possess myself, as far as was permissible, of the facts of this very extraordinary discovery. . . . Of course, I can as yet give no precise details as $\mathbf{M}$. Daguerre naturally objects to impart them to anyone, till he has received definite answer from the Government, with whom he is in treaty for the sale of his secret. I should add that the discovery is authenticated past the power of question by the testimonials of such men as Biot, von Humboldt and M. Arago. His earlier sketches of four years ago have a slight haziness ; some of his last works have the force of Rembrandt's etchings." Of the various subjects of Daguerre pictures, the correspondent mentioned the Quays of Paris, the Louvre and Notre Dame, the picture of the last having been taken in the rain.

Daguerre had begun life as an inland revenue officer, then became a stage painter, and in 1822, in conjunction with M. Bouton, opened the Diorama in Paris, which for seventeen years was a great attraction. For many years he endeavoured to produce permanent pictures by the action of sunlight, and collaborated with Nicéphore Niepce (1765-1833). Daguerre's pictures were produced on plates of silver covered with a film of iodide. After exposure, the plates were developed by means of mercury vapour and fixed in a bath of hyposulphite of soda.

\section{Parallax of $\alpha$ Centauri}

ON January 9, 1839 , the discovery of the parallax of $\alpha$ Centauri was communicated to the Royal Astronomical Society by Thomas Henderson (17981844), the first Astronomer Royal for Scotland, to which office he had been appointed in 1834, a year after his return from the Cape of Good Hope. "With a view," said Miss Clerke, "to correcting the declination of the lustrous double star $\alpha$ Centauri . . . he effected a number of successive determinations of its position, and on being informed of its very considerable proper motion $\left(3 \cdot 6^{\prime \prime}\right)$ annually he resolved to examine the observations already made for possible traces of parallactic displacement. This was done on his return to Scotland. . . From the declination measurements made at the Cape and duly reduced, a parallax of about one second of are clearly emerged . . . but, by perhaps an excess of caution, was withheld from publication until fuller certainty was afforded by the concurrent testimony of Lieutenant Meadows' determinations of the same star's right ascension. When at last, January 9, 1839, Henderson communicated his discovery to the Astronomical Society, he could no longer claim the priority which was his due. Bessel had anticipated him with the parallax of 61 Cygni by just two months."

\section{William MacMichael (1784-r839)}

Dr. William MacMichagl, an eminent London physician, who died on January 10, 1839, was born at Bridgnorth in Shropshire in 1784, the son of a 